\title{
Late Cretaceous/Early Paleocene Biostratigraphy of the Northern Portion of the Bornu Basin, Nigeria
}

\author{
Peter S. Ola ${ }^{1}$, John A. Adekoya ${ }^{2}$, Solomon O. Olabode ${ }^{1}$ \\ ${ }^{1}$ Department of Applied Geology, The Federal University of Technology, Akure, Nigeria \\ ${ }^{2}$ Department of Geology, Osun State University, Oshogbo, Nigeria \\ Email:psola@futa.edu.ng
}

Received 18 June 2014; accepted 12 July 2016; published 15 July 2016

Copyright (C) 2016 by authors and Scientific Research Publishing Inc.

This work is licensed under the Creative Commons Attribution International License (CC BY).

http://creativecommons.org/licenses/by/4.0/

(c) (i) Open Access

\begin{abstract}
Ditch cutting samples from Kasade-1 well were processed for microfauna, nannofossil and palynomorphs to throw more light on biostratigraphic events in the northern portion of the Bornu Basin, Nigeria. The lower section of the well within interval 990 - $1565 \mathrm{~m}$ yielded fairly abundant foraminifera species, while the upper section was barren. Palynomorph distribution follows the same pattern as observed for foraminifera except that few fresh-water algal species, Botryococcus braunii, were recovered from the upper section. The samples are devoid of nannofossil but contain few ostracod species, echinoid remains and fish tooth. Recognition of two planktonic foraminifera zones, Globotruncanella havanensis and Globotruncana aegyptiaca, enabled the delineation of the Campano-Maastrichtian and Maastrichtian boundary. The Cretaceous Tertiary boundary was inferred based on the top occurrence of palynomorph Dinogymnium euclaense. An abrupt truncation in the distribution of foraminifera species at a depth of about 990 m suggests unconformity, a widely reported event that followed the Santonian squeeze in the entire mega-Chad Basin.
\end{abstract}

\section{Keywords}

Microflora, Microfauna, Cretaceous, Unconformity, Formation

\section{Introduction}

The renewed search for hydrocarbon in the Bornu Basin, Nigeria (Figure 1), makes the understanding of biostratigraphic events in the basin now of paramount interest. Twenty three exploration wells of which Kasade-1 well is one have been drilled in the basin. So far, five of these wells have been studied for their stratigraphic 


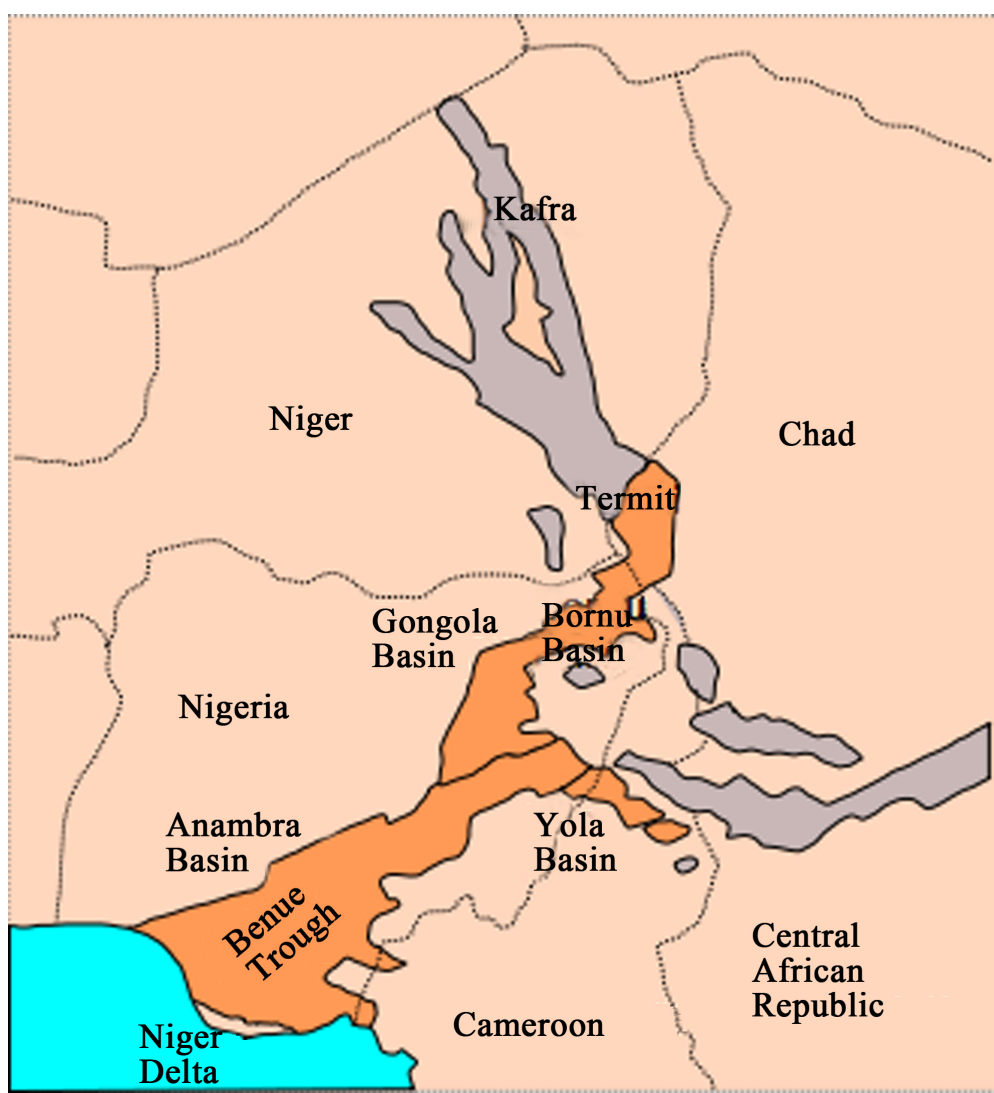

Figure 1. Location map of the Bornu Basin within the West and Central African Rift System (WCARS) (modified after Alalade and Tyson 2010).

significance. The oldest dated sequence in the basin, termed pre-Bima, is Albian [1]. Studies of the dinoflagellate cysts of the deepest well, Kinasar-1, in the basin reveals that the well bottomed within the Cenomanian sediments [2]. Earlier study of the sequences penetrated by the well using ostracod reveals age of Albian at a depth of about $1750 \mathrm{~m}$ [3]. The age of the fossiliferous interval of Kemar-1 as studied by [4] also shows early Turonian at the base. According to [5], the Fika and Gongila Formations contain Turonian to Santonian ostracods but lack palaeontological evidence for marine Santonian to Campanian sediments. Paleoenvironment within this intercontinental basin ranges from fluviomarine through coastal deltaic to shallow marine/open marine. Details of the lithostratigraphic succession in the basin are contained in [6] [7].

Significant outcrop studies both within and outside the basin (because of its rare occurrence in the basin) have been carried out to make biostratigraphic deductions in the basin. [8] is notable among these works who investigated the Upper Cretaceous Gongilla and Pindiga Formations and recognized seven ammonite zones in the Upper Cenomanian-Lower and Middle Turonian strata of the Benue Trough, which have been somewhat correlated with the Fika Formation in the Bornu Basin; [9] dated the Kerri-Kerri Formation Paleocene on the basis of pollen and spores; and [10] assigned age to the Kerri-Kerri Formation based on Shell-BP Palynologists dating scheme.

This study attempts to integrate the study of both microfauna and microflora for a better resolution of biostratigraphic events in the Bornu Basin. It is hoped that the study would serve as a data base for establishing a globally acceptable biozonation scheme for the basin.

\section{Geological Setting of the Study Area}

Kasade-1 well is one of the relatively shallow wells drilled to a total depth (TD) of $1510 \mathrm{~m}$ in search of petroleum in the Bornu Basin. The Bornu Basin constitutes the Nigerian portion of the Chad Basin that is made up of some oil producing basins like the Termits, Doseo, Doba and Bongor. The Chad Basin is an inland rift basin 
which is part of the West and Central African Rift System (WCARS) first clearly described by [11]. The origin of the basins in the WCARS has been attributed to the tectonic movements associated with Gondwana land break-up and the separation of South America from Africa through the extension of wrench fault zones (Transform faults) to the Gulf of Guinea and propagation of strike slip faults (rift) from the Gulf into the Precambrian basement of the African continent [11]-[14]. Some workers (e.g. [13] [15] [16]) believe that the location and direction of the Cretaceous rifts are presaged by the occurrence of pre-existing major lineaments and faults in the Pan African mobile belt.

Throughout the Cretaceous, rifting and sedimentation occurred in a variety of tectonic settings within the West and Central Africa forming fault bounded sub-basins, mostly of a "pull apart" type; thus the lithostratigraphy of the sub-basins differs from one area to another. The sedimentary successions in the sub-basins were deposited under varying sedimentary environments-continental to marine. In the area of Lake Chad and parts of Sudan, sedimentary sections are over 10,000 m thick. In other areas, values between $4000 \mathrm{~m}$ and $7000 \mathrm{~m}$ are common [16] [17]. In most of the rift systems, regional post-rift subsidence has resulted in the deposition of Tertiary to Recent sediments, which may be up to $4000 \mathrm{~m}$ [6]. The oldest sediments found within the rifts of West and Central Africa are Neocomian-Barremian in age and are contained in narrow fault-bounded troughs in northern Cameroon and southern Chad [16] [18]. Stratigraphic succession and their nomenclature in the basin are as shown in Figure 2.

\section{Materials and Method}

\subsection{Materials}

Two hundred and eighty six ditch cutting samples retrieved within interval of 60 - $1565 \mathrm{~m}$ of Kasade- 1 were used for this study. The ditch cutting samples were portioned into four for sedimentolodic, palynologic and micropa-

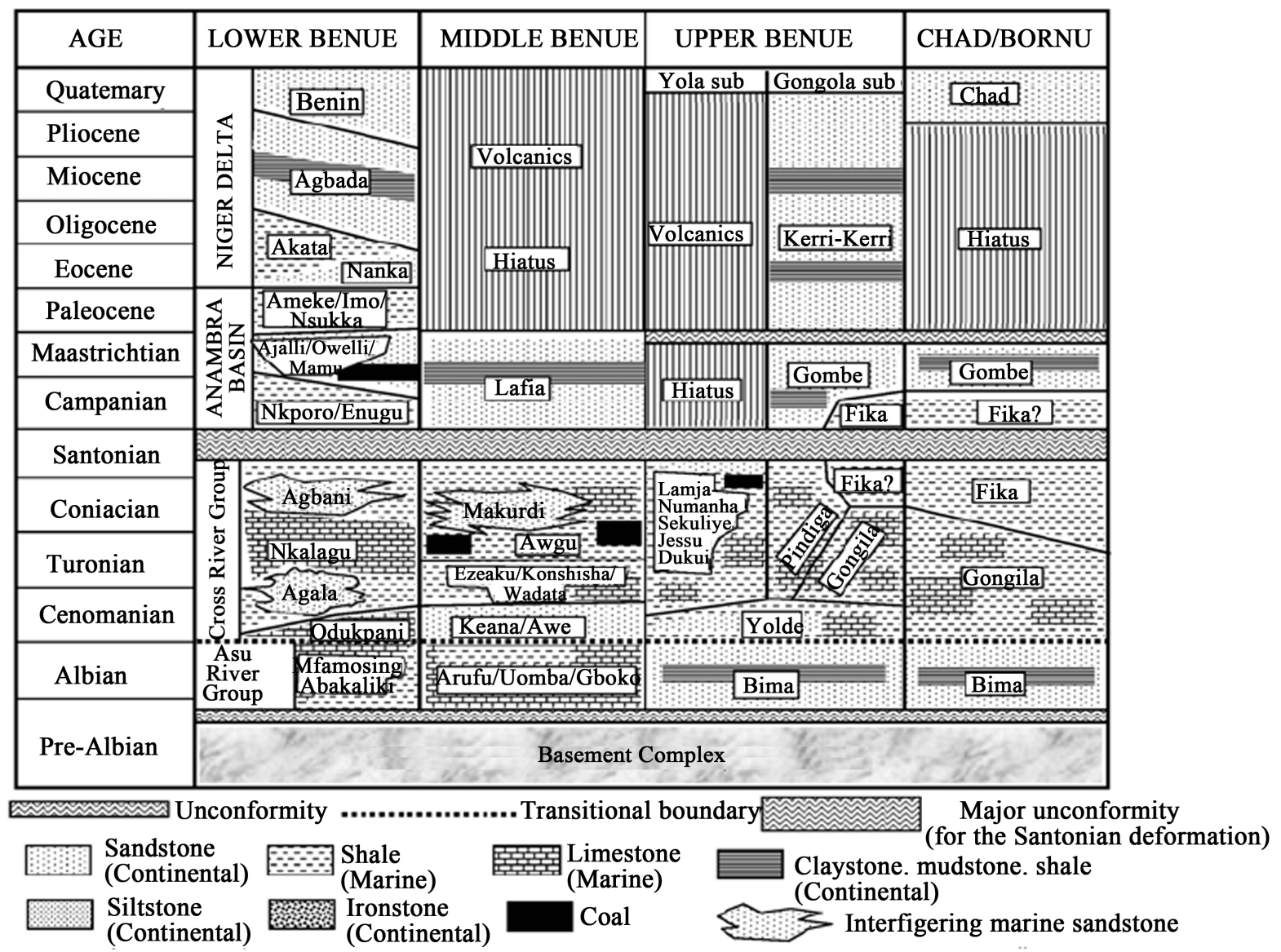

Figure 2. Stratigraphic succession in the Bornu Basin correlated through the Benue trough to the Niger delta. 
laeontologic studies. The remaining portion was kept as reserve.

\subsection{Methods}

\subsubsection{Sedimentology}

The operations employed in the sedimentological studies of the cuttings include a gentle wash of each of the samples with running water, as well as physical observation, microscopic examination and chemical tests of the samples using dilute hydrochloric acid. No fluoroscopic examination was carried out.

\subsubsection{Micropalaeontology}

The two hundred and eighty six ditch cutting samples retrieved within interval of 60 - 1565 m of Kasade-1 well were composited to forty three and processed for foraminifera and accessory microfauna. Twenty grams of each of the dried samples were soaked in kerosene for 20 minutes. Samples were decanted of kerosene and then soaked in soap solution overnight to allow for sufficient disintegration of the samples. Soaked samples were subsequently washed through a $63 \mu \mathrm{m}$ sieve under jet of water until samples were freed of mud. The resultant residues were dried in an oven at temperature below $100^{\circ} \mathrm{C}$. Thereafter, foraminifera species were recovered into slides (cellules) and identified under a stereoscopic reflected light binocular microscope. Scanning Electron Photomicrograph of identified specimens was taken.

\subsubsection{Nannofossils}

Shale samples were carefully selected for this study. Two grams of crushed sample were dispersed in water in test tubes. The resultant suspension from each sample was then pipetted into $22 \times 40 \mathrm{~mm}$ glass slide cover slips. The pipetted suspension on cover slips was dried at about $60^{\circ} \mathrm{C}-70^{\circ} \mathrm{C}$. Dried suspension on cover slips was then mounted on glass slides using Norland Adhesive. The slides were cured under ultra violet light and examined for nannofossils under polarized light, stereoscopic microscope.

The samples for palynological analysis of the Kasade- 1 well were selected and composited at $25 \mathrm{~m}$ intervals for their palynomorph content. Spores and pollens were recovered by treating $20 \mathrm{~g}$ of each sample with hot hydrochloric acid to remove carbonates. Samples were then digested in hydrofluoric acid inside a fume cupboard before they were treated with hydrochloric acid $(\mathrm{HCl})$ and wet-sieved through a $5 \mu \mathrm{m}$ mesh polypropylene sieve. The Branson Sonifier 250 was employed during sieving to facilitate complete removal of silt and clay particles. Sieved residues were oxidized using concentrated nitric acid $\left(\mathrm{HNO}_{3}\right)$. Oxidized residues were mounted on glass slides using Norland Adhesive and then cured in ultraviolet (UV) light. Slides were examined for palynomorphs under polarized light, stereoscopic microscope.

\section{Result and Discussion}

\subsection{Sedimentology}

The sequences penetrated within this well consists of shales, occasionally with subordinate carbonates; shaly sand; sandy shale; and coarse grained, poorly sorted sand that are occasionally ferruginized. Absence of core samples hampered proper lithofacies definition for the well. The upper section of the well (down to a depth of $60 \mathrm{~m}$ ) where samples were not available are considered to be the prevalent Recent alluvium deposits that covers most of the surface area of the basin.

\subsection{Biostratigraphy}

\subsubsection{Microfauna}

From the forty-three (43) composited ditch cutting samples taken within the interval of 60 - $1565 \mathrm{~m}$ of Kasade1 well and processed for foraminifera and accessory microfauna, only fifteen (15) foraminifera species were recovered. Five (5) of these were planktonic species while ten (10) were agglutinating species. Few ostracod species, echinoid remains and fish tooth were also recovered. The stratigraphic distribution, age and paleobathymetric ranges of the species are presented in a Stratabug spreadsheet (Figure 3).

\subsubsection{Planktonic Foraminifera Zones}

Two planktonic foraminifera zones have been recognized based on the Cretaceous planktonic foraminiferal 


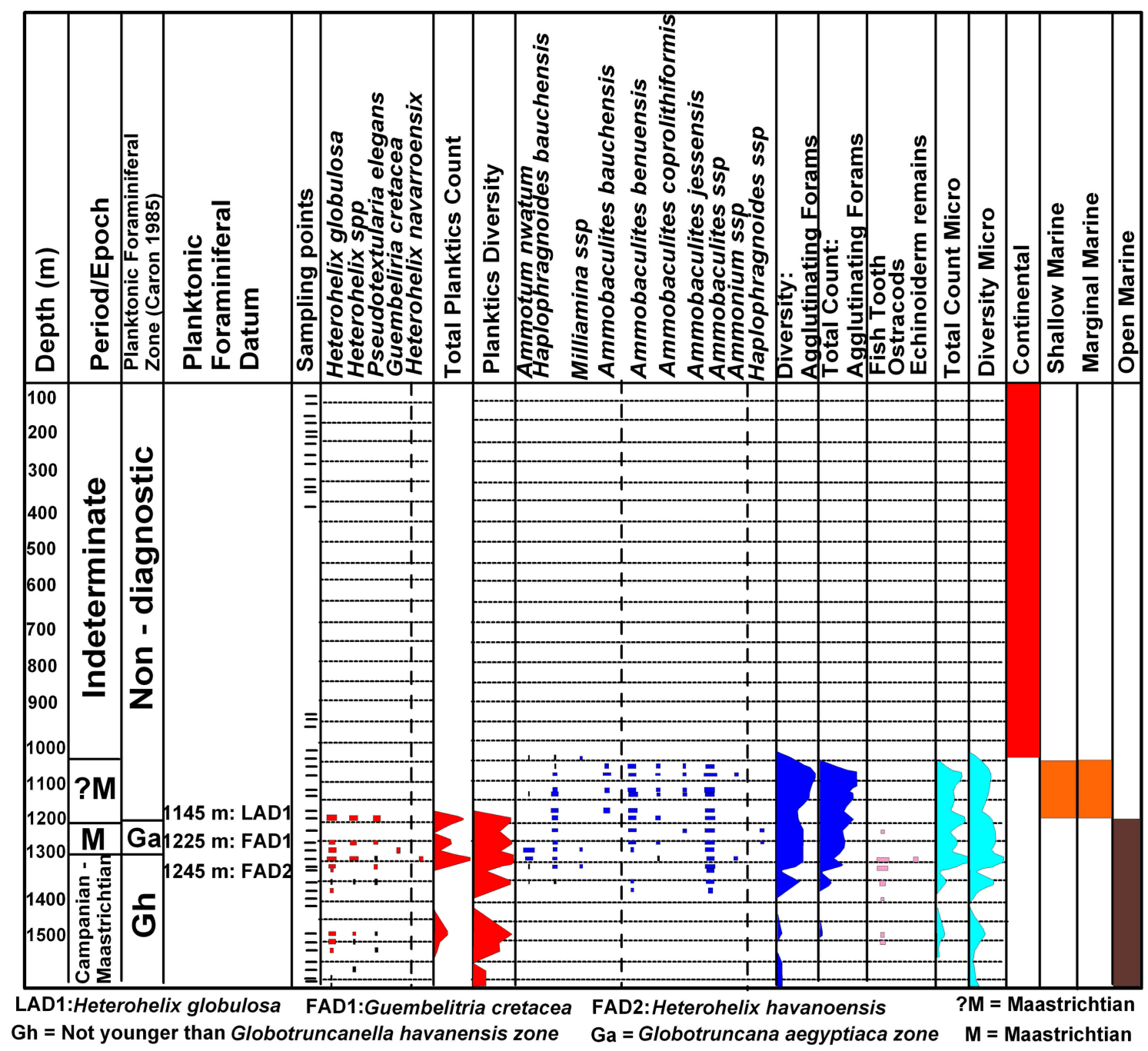

Figure 3. Microfauna biostratigraphic chart of Ngor 1 well, Bornu Basin, Nigeria.

zonation scheme of [19]. These are the Globotruncanella havanensis and Globotruncana aegyptiaca zones (Figure 3).

Stratigraphic Interval: 1245 - 1565 m

Planktonic Foraminiferal Zone: Globotruncanella havanensis and possibly older zone

Age: Campano-Maastrichtian (Upper Cretaceous)

Diagnostic Criteria:

The top of this interval is delineated by the First Appearance Datum (FAD) of Heterohelix navaroensis at $1245 \mathrm{~m}$. The interval is characterized by the occurrence of Upper Cretaceous planktonic foraminifera species such as Heterohelix globulosa, Pseudotextularia elegans and species of Heterohelix. Agglutinating foraminifera species such as Ammotium nwalium, Haplophragmoides bauchensis, Ammobaculites benuensis and species of Ammobaculites were recorded within this interval. These species have been recorded in Cretaceous sediments of the Benue Trough and Chad Basin by [20]. The base of this interval is placed tentatively at $1565 \mathrm{~m}$, the deepest sample studied for Kasade-1.

Stratigraphic Interval: 1145 - $1245 \mathrm{~m}$

Planktonic Foraminiferal Zone: Globotruncana aegyptiaca zone

Age: Maastrichtian (Upper Cretaceous)

Diagnostic Criteria:

Top of the interval is marked by the Last Appearance Datum (LAD) of Heterohelix globulosa at $1145 \mathrm{~m}$. The 
interval is characterized by the occurrence of Upper Cretaceous planktonic species such as Heterohelix globulosa, H. navaroensis, Pseudotextularia elegans, Guembelitria cretacea and species of Heterohelix. The agglutinating foraminifera species Ammobaculites bauchensis, Ammobaculites benuensis, A. jessensis, A. coprolithiformis, Haplophragmoides bauchensis and species of Ammobaculites, Ammotium, Milliammina and Haplophragmoides were also recorded within this interval. The base of the interval is marked by the FAD of Heterohelix navaroensis at $1245 \mathrm{~m}$.

Stratigraphic Interval: 990 - 1145 m

Planktonic Foraminiferal Zone: Non Diagnostic

Age: Maastrichtian (Upper Cretaceous)

Remark: The top of this interval which is placed at $990 \mathrm{~m}$ is suspected to be an erosional or unconformity surface owing to abrupt truncation in the distribution of foraminifera species. The interval is devoid of planktonic species. It is characterized by relatively abundant agglutinating species such as Ammotium nwalium, Haplophragmoides bauchensis, Ammobaculites bauchensis, A. benuensis, A. coprolithiformis, A. jessensis and species of Ammobaculites, Ammotium and Haplophragmoides.

These species have been recorded by [20] in the Upper Cretaceous of Benue Trough and Chad Basin. Therefore, a probable Maastrichtian age is deduced for this interval based on its stratigraphic position and the microfauna assemblage.

Stratigraphic Interval: 60 - $990 \mathrm{~m}$

Planktonic Foraminiferal Zone: Non Diagnostic

Age: Indeterminate

Remark: The interval is barren of foraminifera species. Hence, palynological evidence is relied upon for the dating of this interval.

\subsection{Calcareous Nannofossil}

A total of forty two (42) samples were processed for calcareous nannofossils study. Specifically shale samples were carefully selected at various interval of $10-50 \mathrm{~m}$. The result of the analysis shows that the entire well section was barren of nannofossils. This absence of nannofossils in the well section is thought to be closely related to a non-marine to shallow water environment of deposition. This can be confirmed from the paleobathymetric data from foraminifera, as well as the distribution of dinocysts (from palynological analysis) in the well section.

\subsection{Palynomorph Biostratigraphy}

The samples for palynological analysis of the Kasade- 1 well were selected and composited at $25 \mathrm{~m}$ intervals for their palynomorph content. The palynofloral assemblages were moderately rich and fairly diverse especially within the interval 745 and $1565 \mathrm{~m}$ of the well (Figure 4). The upper section (60 - $745 \mathrm{~m}$ ) of the well was very sparse in pollen, spores and dinoflagellate cysts (palynomorphs). The assemblage is quantitatively dominated by Ephedripites multicostata, Ephedripites sp., Graminidites sp., Gemmatriporites sp., Monocolpites marginatus, Zlivisporis blanensis, Cyathidites minor, Cyathidites sp. and Gleichemidites sp. Dinoflagellate cysts and microforaminiferal wall linings were also recorded with common Botryococcus braunii especially within the interval $740-1385 \mathrm{~m}$.

\section{Palynological Zonation}

The Kasade-1 well penetrated the P100-P200 zones of [21], which are further correlated with Odontochitina operculata-Dinogymnium euclaensis zones and Apectodimium homomorphum-Danea mulabilis zones of [22]. A Campanian-Early Paleocene age has been assigned to the Kasade-1 well (Figure 4). Details of the palynological and assemblage zones are discussed as follows:

P200 Zone (Apectodimium homomorphum Assemblage-Danea mutabilis zone)

Interval: 60 - $815 \mathrm{~m}$

Age: Early Paleocene

Diagnosis: The top of this zone is placed at the $60 \mathrm{~m}$, the shallowest depth analysed, while the base is marked by the top occurrence of Dinogymnium euclaense at $815 \mathrm{~m}$. This interval is very sparse in pollen and spores. Few specimens of freshwater Botryococcus braunii were recorded within interval 185 - $415 \mathrm{~m}$.

P100 Zone (Dinogymnium euclaense zone) 


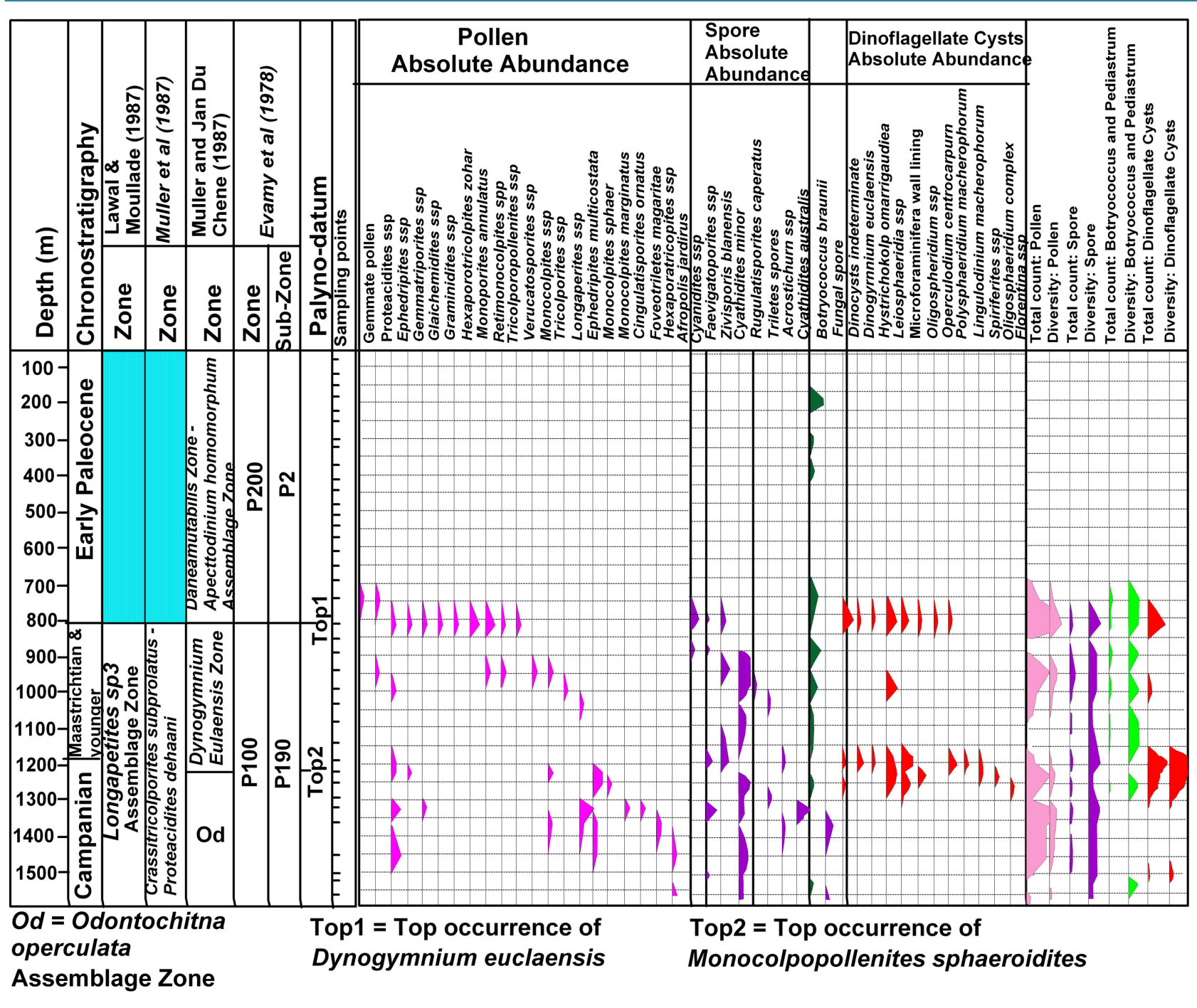

Figure 4. Palynomorphs distribution chat and biostratigraphy of Kasade-1 well Bornu Basin Nigeria.

Interval: 815 - $1200 \mathrm{~m}$

Age: Maastrichtian

Diagnosis:

The top of the zone is defined by the top occurrence of Dinogymnium euclaense at $815 \mathrm{~m}$, while the base is marked by the top occurrence of Monocolpopollenites sphaeroidites at $1200 \mathrm{~m}$. This zone is further characterized by the presence of Dinogymnium euclaense, Longapertites sp., Ephedripites multicostata and Cyathidites australis.

P100 Zone (Odontochitina operculata Assemblage zone)

Interval: 1200 - $1565 \mathrm{~m}$

Age: Campanian

Diagnosis: The top occurrence of Monocolpopollenites sphaeroidites defines the top of this zone at $1200 \mathrm{~m}$, while the base is placed at $1565 \mathrm{~m}$, the deepest sample analysed. The regular records of Monocolpopollenites sphaeroidites and the presence of Hexaporotricolpites sp. further characterized this zone.

\subsection{Paleoecology}

Interval 1145 - $1565 \mathrm{~m}$

The assemblage of this interval includes planktonic species such as Pseudotextularia elegans, Heterohelix glo- 
bulosa, as well as agglutinating species such as Ammobaculites bauchensis, and A. benuensis. According to [23] the known ecology of Ammobaculites bauchensis and A. benuensis is normal marine to brackish shelf. In the same vein planktonic species of Ammobaculites and Haplophragmoides indicate open marine conditions. The relatively abundant occurrence of these foraminifera species within this interval suggests the sediments were probably deposited during the Campano-Maastrichtian marine transgressions.

Interval 990 - 1145 m (Figure 3)

The non-recovery of planktonic foraminifera species and the dominance of agglutinating foraminifera represented mainly by the genus Ammobaculites points to a shallow to marginal marine environment of deposition within this interval.

Interval 60 - 990 m (Figure 3)

This interval is barren of foraminifera suggesting the cessation of marine influence at the location of Kasade-1 probably during the post Maastrichtian times or may be associated with the prevalent global climatic condition leading to the Cretaceous-Tertiary (K-T) boundary mass extinctions. The occurrence of the freshwater algae, Botryococcus braunii within interval 225 - 415 m however suggests freshwater environment.

\subsection{Summary of Biostratigraphy and Its Implications}

The summary of biostratigraphic events is presented in Figure 5. Generally starting from the lower section of

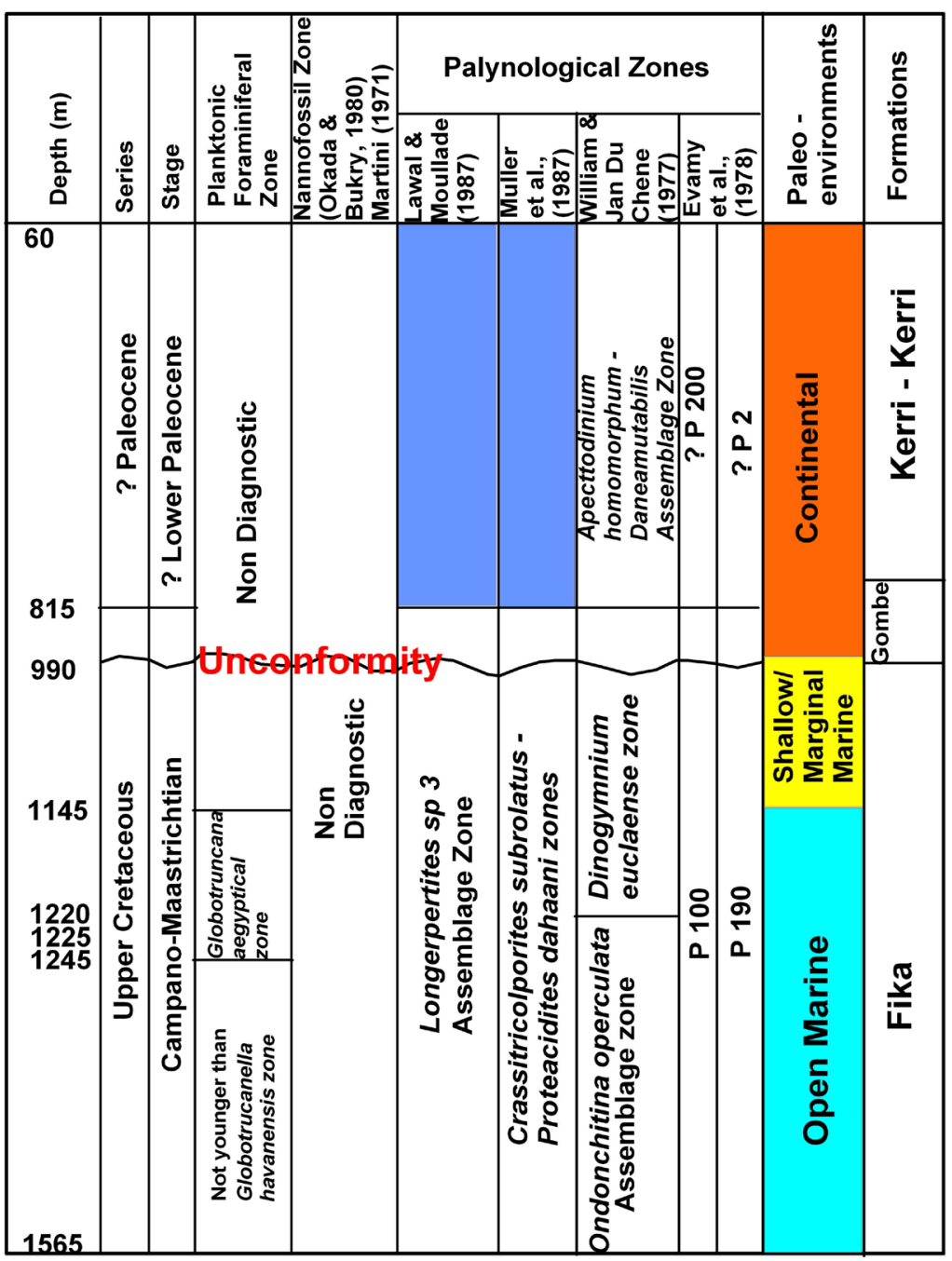

Figure 5. Summary of biostratigraphic events based on Kasade-1 well in the Bornu Basin. 
the well, marine evidences that gradually gave way to continental/freshwater influences in the Late Maastrichtian-Early Paleocene times were observed. Some regional level unconformity surfaces have been reported in all the WCARS basins based on seismic interpretation. In Kasade- 1 a fossil distribution truncation was observed at a depth of $990 \mathrm{~m}$ suggesting an unconformity. The occurrence of this unconformity surface just before the Palaeocene suggests its link with the post-Santonian squeeze erosion that has been widely reported in the whole Chad Basin [10]-[13]. Following the erosion, the Gombe Formation was deposited (Figure 5). Again, another observed abrupt truncation in planktonic foraminifera distribution at about $1145 \mathrm{~m}$ and the continued occurrence of agglutinated foraminifera at shallower depths to the exclusion of the planktonic forms suggest shoaling and change in the depositional regime that resulted in facies dislocation at about this depth. Marine conditions held sway during Campano-Maastrichtian, which led to the deposition of the Fika Shale.

The preponderance of marine planktics at the total depth of the well suggests that the continental Bima Formation is yet to be penetrated by this well. In addition, the chance of occurrence of marine shale that could serve as source rock below this depth is high, except that this study has not tested the maturity level of the shales at the total depth of the well. The implication of these on hydrocarbon exploration in the basin is important and calls for organic geochemical study of the shales.

\section{Conclusion}

Based on the top occurrence of Dinogymnium euclaense at $815 \mathrm{~m}$ in the section of the studied Kasade- 1 well, the Cretaceous/Tertiary boundary was inferred. Both the foraminifera and palynomorph contents enabled the recognition of the Upper Cretaceous sections of the well. The top occurrence of Monocolpopollenites sphaeroidites was used to define the Campanian. The sedimentary sequences in the interval 990 - $1565 \mathrm{~m}$ yielded fairly abundant foraminifera species, suggesting shallow to open marine depositional environment during the upper Cretaceous in the basin. The absence of nannofossil in the well ditch cutting samples is probably a reflection of how shallow the level of marine events was in the basin. Because the well was stopped within marine shale bed it is suggested that the well could still be drilled further in search of hydrocarbon, although it is desirable to check first the level of the shale maturity for hydrocarbon generation.

\section{Acknowledgements}

This research work was sponsored from the PTDF 2011/2013 Research Grant. The facility of Crystal Age Laboratory was used. These are acknowledged with thanks.

\section{References}

[1] Ola-Buraimo, A.O. (2012) Lithostratigraphy and Palynostratigraphy of Tuma-1 Well Bornu Basin, North Eastern Nigeria. Journal of Biological and Chemical Research, 29, 206-223.

[2] Yikarebogha, Y., Oloto, I.N., Soronnadi-Ononiwu, G.C. and Omoboriowo, A.O. (2013) Dinoflagellates Cyst Biozonation for Upper Cretaceous Succession of Kinasar-1 Well, Central Chad Basin, North Eastern Nigeria. International Journal of Science and Technology, 30, 108-117.

[3] Okosun, E.A. (1995) Review of the Geology of Bornu Basin. Journal of Mining and Geology, 31, 113-172.

[4] Adegoke, K.A. (2012) Biostratigraphy and Depositional Environment of the Sediments in Bornu Basin, North Eastern Nigeria. International Journal of Science and Technology, 5, 2800-2809.

[5] Hamza, H., Obaje, O.G. and Obioso, E.O. (2002) Foraminiferal Assemblage and Palaeoenvironment of the Fika Shale, Bornu Basin, Northern Nigeria. Journal of Mining and Geology, 38, 49-55. http://dx.doi.org/10.4314/jmg.v38i1.18774

[6] Alalade, A. and Tyson, R.V. (2010) Hydrocarbon Potential of the Late Cretaceous Gongila and Fika Formations, Bornu (Chad) Basin, NE Nigeria. Journal of Petroleum Geology, 33, 339-354. http://dx.doi.org/10.1111/j.1747-5457.2010.00483.x

[7] Avbovbo, A.A., Ayoola, E.O. and Osahon, G.A. (1986) Depositional and Structural Styles in the Chad Basin of Northeastern Nigeria. AAPG Bulletin, 70, 1787-1798.

Hamza, H., Obaje, N.G. and Moumouni, A. (2011) Benthonic Foraminiferal Assemblages from the Bornu Basin, Northeastern Nigeria. Journal of Mining and Geology, 48, 91-115.

[8] Popoff, M., Wiedman, J. and De-Klasz, I. (1986) The Upper Creyaceous Gongila and Pindiga Formations, Northeastern Nigeria: Subdivisions Age, Stratigrapic Correlations and Palaeogeographic Implications. Eclogae Geologie Helvetica, 79, 343-363. 
[9] Adegoke, O.S., Jan du Chene, R.E., Agumanu, E.A. and Ajayi, P.O. (1978) Palynology and Age of Kerri-Kerri Formation, Nigeria. Revista Española de Micropaleontología, 10, 267-283.

[10] Carter, J.D., Barber, W., Tait, E.A. and Jones, G.P. (1963) The Geology of Parts of Adamawa, Bauchi and Borno Provinces in Northeastern Nigeria. Geological Survey of Nigeria Bulletin, 30, 1-108.

[11] Browne, S.E. and Fairhead, J.D. (1983) Gravity Study of the Central African Rift System, a Model of Continental Disruption, 1. The Ngaoundere and Abu Gabra Rifts. Tectonophysics, 94, 187-203. http://dx.doi.org/10.1016/0040-1951(83)90016-1

[12] Fairhead, J.D. (1986) Geophysical Controls on Sedimentation within the African Rift Systems. Geological Society, London, Special Publications, 25, 19-27. http://dx.doi.org/10.1144/gsl.sp.1986.025.01.03

[13] Benkhelil, J. (1988) Structure et bolution giodynamique du bassin intracontinental de la Benin and Nigeria. Bulletin des centres de recherches exploration-production Elf-Aquitaine, 12, 29-128.

[14] Fairhead, J.D. and Binks, R.M. (1991) Differential Opening of the Central and South Atlantic Oceans and the Opening of the Central African Rift System. Tectonophysics, 187, 191-203. http://dx.doi.org/10.1016/0040-1951(91)90419-S

[15] Naggy, R.M., Ghuma, M.A. and Rogers, J.J.W. (1976) A Crustal Suture and Lineament in North Africa. Tectonophysics, 31, 67-72. http://dx.doi.org/10.1016/0040-1951(76)90115-3

[16] Genik, G.J. (1992) Regional Framework, Structural and Petroleum Aspects of Rift Basins in Niger, Chad and Central African Republic (C.A.R.). Tectonophysics, 213, 169-185. http://dx.doi.org/10.1016/0040-1951(92)90257-7

[17] Cratchley, R., Louis, P. and Ajakaiye, D.E. (1984) Geophysical and Geological Evidence for the Benue-Chad Basin Cretaceous Rift Valley System and Its Tectonic Implications. Journal of African Earth Sciences, 2, 141-150. http://dx.doi.org/10.1016/S0731-7247(84)80008-7

[18] Guiraud, R. and Maurin, I. (1992) Early Cretaceous Rifts of Western and Central Africa: An Overview. In: Ziegler, P.A., Ed., Geodynamics of Rifting, Volume II. Case History Studies on Rifts: North and South America and Africa. Tectonophysics, 213, 153-168. http://dx.doi.org/10.1016/0040-1951(92)90256-6

[19] Caron, M. (1985) Cretaceous Planktonic Foraminifera. In: Bolli, H.M., Saunders, J.B. and Perch-Nielsen, K., Eds., Plankton Stratigraphy, Cambridge University Press, Cambridge, 11-86.

[20] Petters, S.W. (1979) Central West African Cretaceous-Tertiary Benthic Foraminifera and Stratigraphy. Palaeontographica Abteilung A, 179, 1-104.

[21] Evamy, B.D., Haremboure, J., Kamerling, P., Knaap, F.A., Molloy, F.A. and Rowland, P.H. (1978) Hydrocarbon Habitat of Tertiary Niger Delta. Bulletin of the American Association of Petroleum Geologists, 62, 1-39.

[22] Williams, G.L. (1977) Dinocysts: Their Paleontology, Biostratigraphy and Paleoecology. In: Ramsay, A.T.S., Ed., Oceanic Micropaleontology, Academic Press, London, 1231-1325.

[23] Gebhardt, H. (1997) Cenomanian to Turonian Foraminifera from Ashaka (NE Nigeria): Quantitative Analysis and Palaeoenvironmental Interpretation. Cretaceous Research, 18, 17-36. http://dx.doi.org/10.1006/cres.1996.0047

\section{Submit or recommend next manuscript to SCIRP and we will provide best service for you:}

Accepting pre-submission inquiries through Email, Facebook, Linkedin, Twitter, etc

A wide selection of journals (inclusive of 9 subjects, more than 200 journals)

Providing a 24-hour high-quality service

User-friendly online submission system

Fair and swift peer-review system

Efficient typesetting and proofreading procedure

Display of the result of downloads and visits, as well as the number of cited articles

Maximum dissemination of your research work

Submit your manuscript at: http://papersubmission.scirp.org/ 